\title{
Exploring Nursing Students Engagement in Their Learning Environment
}

\author{
Amna Abdul Sattar ${ }^{1, *}$, Rubina Kouar ${ }^{2}$, Syed Amer Gillani ${ }^{3}$ \\ ${ }^{1}$ Student of nursing education (Post RN BScN), Lahore School of Nursing, The University of Lahore, Lahore, Pakistan \\ ${ }^{2}$ Supervisor, Lahore School of Nursing, The University of Lahore, Lahore, Pakistan \\ ${ }^{3}$ Dean, Faculty of Allied Health Sciences, The University of Lahore, Lahore, Pakistan \\ *Corresponding author: abdulsattar196@gmail.com
}

\begin{abstract}
Student engagement is seen more than to just involve student during organization time its meaning has become more vast than previously assumed. Now, it is viewed by diverse aspects not a one aspect consider enough to define engagement. Student's emotional, cognitive and behavioral participation in their learning environment is considered as true engagement. It is not also helpful to engage student in course material but also help students to get better outcome. Nursing student engagement is essential in this respect that they have to pay double role. They not only engage in class room but also in clinical setting. In this research Cross-sectional study was done. Student Engagement Questionnaire (SEQ) developed by David Kember and Doris Leuing was used. Sample size of $n=135$ undergraduate students were taken. Data analyzed by using software SPSS 21. Bench markers of student engagement were analyzed by Pearson correlation and association between students engagements were analyzed by regression analysis. Results shows higher mean score in domain of meaningful process. Component of student engagement critical thinking, creative thinking and computer skills were highest mean score. Student shows the highest perception of work load and stress. There were no significant relationship between student engagement and self-reported cumulative GPA.
\end{abstract}

Keywords: student engagement, nursing students, learning environment, learning outcome, Student Engagement Questionnaire, Student Engagement Process

Cite This Article: Amna Abdul Sattar, Rubina Kouar, and Syed Amer Gillani, "Exploring Nursing Students Engagement in Their Learning Environment." American Journal of Nursing Research, vol. 6, no. 1 (2018): 18-23. doi: 10.12691/ajnr-6-1-3.

\section{Chapter One}

\subsection{Introduction}

Student engagement is seen more than to just involve student during organization time its meaning has become more vast than previously assumed. The definition has been changed of engagement after conceptualization on engagement. Now, it is viewed by diverse aspects not a one aspect consider enough to define engagement. Student's emotional, cognitive and behavioral participation in their learning environment is considered as true engagement. These three aspects further cover the several parts, in which including, concentration teamwork, active participation in class and group work, creative thinking, concentration, collaboration [1].

Student engagement is helpful to assess nursing quality in academy and the success of student graduation, by assessing engagement institution can manipulate the outcome by applying intervention before the consequence may appear. As studies shows that student can be retain in organization by increasing belonging and engagement in their organization and learning environment. Engagement has a major role to persist the student in their enrolled course [2]. It's mean if student experiencing low engagement their chances to dropout from course is also higher. Student engagement outcome is not only a predictor of students retention but studies shows that it also helps student in academic success, to achieve higher GPA. Increase engagement increase the chance of course completion in which student enrolled it help to balance the enrolled credit hour and completed credit hour which is biggest predictor to assess retention in freshmen who retain and become sophomore in the same organization. There is positive relation between academic success measures and student engagement in learning environment [3].

Kember, Leung, and $\mathrm{Ma}$ [4] research prove that student who is graduating from university should have following competencies for his lifetime experiences, adaptability, critical thinking, creative thinking, problem solving and self-directed learning. As well student have the ability to work with others in group, should have communication skills and interpersonal relationships skill.

In nursing studies, student performed dual role unlike other discipline nurses not only to have engage in classroom but also in clinical setting. Through active engagement they in both areas help student to become more effective, current, and knowledgeable as they became engaged nurses [1]. However, student engagement is not only the concern in nursing discipline but it is also 
basic issue of every educational organization to track engagement of every student in every enrolled course.

It is visible that biggest outcome of student engagement is retentions and persistence in their course because by only retention in course they can strive for higher GPA, and they left organization by getting their graduation degree. So engagement in learning environment not only effect on critical thinking, problem solving and interpersonal relationship skills but also helps the student to earn more pay then the person who don't own the graduation degree. According to research a bachelor's degree holder 2011 earn working full time 66,500\$ as compared to high school diploma holder who only earn $21,100 \$$. In addition, higher school diploma holder earn less late age financial benefits compared to college student graduate [5]. Also when more citizen are college graduate the whole nation will be benefited as their health will improve, increase school readiness of children, more opportunities for jobs and decrease poverty [6].

\subsection{Problem Statement}

It is all over observed that mostly universities have good learning environment with all resources necessary for student learning. Despite, all of this students never score good GPA. There are too many factor behind this, student engagement is consider one of them which have crucial role in student learning. This study interested to measuring the engagement and estimate its influence on GPA score. Because if engagement is less in their learning environment it cause frustration, low satisfaction, negative experience and cause to increase of failure in enrolled course. Through exploring student engagement in learning environment can help to improve the outcome of learning [7].

\subsection{Purpose of the Study}

This study helps to explore student engagement in their learning environment.

\subsection{Significance of the Study}

a) This study help the participants to modify their own engagement with their learning environment and course in which they enrolled.

b) Helps the organization to improve the area that's engagement develop the outcome of student.

\subsection{Research Questions}

Research questions of this study were:

1. What is the level of student engagement in their learning environment among undergraduate nursing student of University of Lahore?

2. What association between student engagement domain (Meaningful process, Participation and Forced Attention) and outcome of learning in undergraduate nursing students?

\subsection{Definition of Term}

\subsubsection{Student Engagement}

Student engagement has been defined as "participation in educationally effective practices, both inside and outside the classroom, which leads to a range of measurable outcomes" [8] and as "the extent to which students are engaging in activities that higher education research has shown to be linked with high-quality learning outcomes" [9].

\subsubsection{Undergraduate Nursing Program}

Undergraduate nursing program has two tracks to enter in Baccalaureate nursing program. First is direct entry or regular degree program (BSN) in which student enrolled after completing high school certificate and called prelicensure. Second track is after getting nursing diploma course and licensed by nursing council this program called Post-RN BSN.

\subsection{Conceptual Framework}

The conceptual framework is centered on Austin's theory of engagement [10]. The student involvement theory emphasize on what the college student does in order to be an active participant in the learning process [10]. Active participation could include: interacting with faculty and peers, participating in campus organizations, attending campus events, working, studying, and volunteering are all ways in which Astin saw that students could be involved in their learning process [10]. Astin's theory, originally published in 1984, describes the environmental effects on college student progress. In 1996, Astin recommended that levels of involvement occur beside a scale, differ in strength for each student, and diverge between students. The essential concepts of the model are built on the three basics of ideas, surroundings, and productions. The first element, Inputs, refers to the student's demographics, background, and previous experiences. Environment, the second element, explain all of the experiences a student has during college. The third element, Outputs, refers to the student's characteristics, knowledge, attitudes, beliefs, and values that exist after a student has graduated from college. Outputs include outcome indicators such as grade point average, student retention, course performance, and degree completion [10].

\section{Chapter Two}

\subsection{Literature Review}

Active learning is way to engage student in learning course, it allows student to make sense what they are learning, make connection of concepts what they are receiving in their learning course. It assumes to be the important way to engage student in their course material. If student is actively participate in class he/she will think critically, solve problem efficiently. In short, it is the essential; technique of engaging student in their course material [11].

In order to engage student in learning environment cooperative learning considered to have a positive relation it is the part of active learning. According to study by using cooperative learning in the class room teacher expressed that they are satisfied that prepared their student for professional career [12]. Cooperative learning is help 
to educators to provide a tool to give a good education to learner, it is a method through teachers know the need of student for improvement. It helps students to develop interpersonal skills and problem solving. By cooperative learning student, teacher and other student in group work together to achieve the goal [13]. It is part or method to engage student in learning behaviorally.

Another, major part of student engagement in learning environment is teacher student relationship, academic relation between student and teacher is not only important in pre-school setting but also greatly important in higher education. Teacher student relation aids student to increases their progress in study, get academic success, increase course satisfaction, retention, learning methodologies and accomplishment [14].

In cognitive engagement critical thinking is important to evaluate because it links with the further ability to solve problem and create something. Critical thinking includes the constituent skills to the constituent skills of studying opinions, creating inferences using inductive or deductive perceptive, refereeing or assessing, and creating results or resolving problems. It helps person to view things with diverse perspective, develop willingness in person to accept different perspective, develop flexibility, fair mindedness and prosperity to seek reason. This provide student reasoning, help to make judgment and logical reasoning and to make choices and decisions [15]. The research conduct in San Diego to assess student engagement and student learning, 1,352 students from fourteen institutions of four year undergraduate were participants of this research. The result shows that there is optimistic association among student engagement and grades, critical thinking. Engagement, grades and critical thinking of student has positive association that both effect each other [16].

Communication skills is also a sub domain of student engagement, and for the nursing student effective communication is not only classroom but also has a necessary part in clinical development and student should be expert in communication skills. Now, today nurses are plying multiple roles and they should be equipped with the knowledge of communication skills, management, end-of life care, ethical/legal issues and team collaboration [17]. Communication skills are also an important graduate attribute for all disciplines, in Australia a research conducted to explore the engagement in multidisciplinary allied health communication skills. 736 participants were involved from all department of allied health science. Data was collected from student by survey, survey is performed firstly at the starting of semester and then at last of semester. Results exhibits that through the semester highest engagement score was of psychology students. However, lowest scores are of nursing/paramedics student, nursing student though need higher need of communication skills but studies exhibit opposite result [18].

Examining of structural association among students learning outcomes and features that relates these outcome, features including collage environment, class contribution, student-faculty interface and integration of experiences. This study basically focus on learning environment and student's classroom participation on learning outcome. This study is conducted on 18,551 students of universities of Korea. The result shows that class participation, student-faculty communication and class contribution have positive impact on students learning outcome [19].

Another study conducted in Turkey in which student 304 students who were attending the Education Faculty of Anadolu University in Turkey in the year of 2013-2014. Questionnaire of Student Engagement Scale by Gunuc and Kuzu was used. Data analyzed by multiple inferential statistics, there was a significance among the academic achievement and student engagement. This study revealed that emotional, cognitive and behavioral engagement have a strong relation with academic achievement. Furthermore, cognitive engagement is found more important for academic achievement than other engagements [20].

Student nurses performed double role while they are learning, they not only involve in classroom learning but also work at same time in clinical setting. Due to their direct interaction with patient they needs more emphasis in the engagement in their both setting. Now nursing performs evidence-based practices and made evidencebased decisions. So the engagement is plays as the stimulant to caring behavior for their care delivery and for providence of quality with in student and patient interaction [21].

In study nursing student curriculum engagement in their learning environment examined, 250 nursing students participate in research, engagement was assessed by the Student Engagement Questionnaire (SEQ). Results shows that fifty percent students have high mean score in the three engagement domains. Student showed higher engagement in their clinical learning environment [22].

\section{Chapter Three}

\subsection{Research Design}

The research design was quantitative, cross-sectional.

\subsection{Population}

Students from Lahore School of Nursing at University of Lahore, Lahore Pakistan.

\subsection{Inclusion Criteria}

All student who are above the age of 18 year old, willing to participate in study by singing consent, and completed at least one semester of their enrolled course were included in study.

\subsection{Exclusion Criteria}

Students who less than 18 year old, not willing to participate in study, didn't completed their first semester of their enrolled course were excluded in this study.

\subsection{Sample}

Consensus sampling used whole LSN population $(n=135)$ who are meeting the inclusion criteria were the participants of study. 


\subsection{Research Tool}

A close ended questionnaire (5-point likert scale) were filled by the participants. The Student Engagement Questionnaire (SEQ) developed by David Kember and Doris Leuing, the instrument contains 34 total questions on three themes of student engagement which are meaningful process, participation and focused attention [23]. With demographic information in which age, gender, program of study, year of admission and self-reported cumulative GPA.

\subsection{Ethical Consideration}

Participants in the research will take part voluntary. The research study is consisted of a questionnaire with no physical, psychological, and social harm. Informed consent was obtained, if participants was agree than they asked to complete the questionnaire.

\section{Chapter Four}

\subsection{Data Analysis}

The questionnaire were distributed in 137 participants, by using census sampling techniques to gather data. 135 questionnaire returned and 2 questionnaire were missing. Data were collected from all students from Lahore School of Nursing from the spring 2013 to 2016. Data were analyzed by using software SPSS 21 . Descriptive statics were run for demographic data. Correlation between domains of student engagement were analyzed by applying Pearson correlation. Student engagement and outcome association were analyzed with regression analysis.

\subsection{Descriptive Statistics}

Table 1. Demographic Characteristics

\begin{tabular}{|c|c|c|c|c|}
\hline S.No & \multicolumn{2}{|c|}{ Demographic Data } & Frequency & Percentage \\
\hline \multirow{2}{*}{1.} & \multirow{2}{*}{ Gender } & Male & 17 & $12.6 \%$ \\
\hline & & Female & 118 & $87.4 \%$ \\
\hline \multirow{4}{*}{2.} & \multirow{4}{*}{$\begin{array}{l}\text { Age Group of } \\
\text { Participants }\end{array}$} & $18-22$ & 41 & $30.4 \%$ \\
\hline & & $23-27$ & 76 & $56.3 \%$ \\
\hline & & $28-32$ & 17 & $12.6 \%$ \\
\hline & & 33-Above & 1 & $.7 \%$ \\
\hline \multirow{3}{*}{3.} & \multirow{3}{*}{ cGPA } & (A) $3.32-4.0$ & 21 & $15.6 \%$ \\
\hline & & (B) $2.32-3.33$ & 102 & $75.6 \%$ \\
\hline & & (C) $1.1-2.33$ & 12 & $8.9 \%$ \\
\hline \multirow{4}{*}{4.} & \multirow{4}{*}{$\begin{array}{c}\text { Year of } \\
\text { Admission }\end{array}$} & 2013 & 12 & $8.9 \%$ \\
\hline & & 2014 & 29 & $21.5 \%$ \\
\hline & & 2015 & 53 & $39.3 \%$ \\
\hline & & 2016 & 41 & $30.4 \%$ \\
\hline \multirow[b]{2}{*}{5.} & Enrolled Program & BSN 4yrs & 52 & $38.5 \%$ \\
\hline & & $\begin{array}{l}\text { BSN Post } \\
\text { RN 2yrs }\end{array}$ & 83 & $61.5 \%$ \\
\hline
\end{tabular}

\subsection{Student Engagement Process}

There are three domain of student engagement (Meaningful process, Participation and Focused attention), and have 17 sub domain in which seven items measured behavioral engagement and ten item measured emotional engagement (attitude). Total 34 questions address whole process in which question divided respectively as every sub-domain has two questions except feedback to assistance which have three question and teaching for understanding which has one question,

Table 2. Nursing Student Engagement Domain

\begin{tabular}{|c|c|c|c|}
\hline Domain & Sub-domain & Mean & core \\
\hline \multirow{6}{*}{$\begin{array}{l}\text { Meaningful } \\
\text { Process }\end{array}$} & Critical Thinking & $3.83 \pm 0.973$ & \multirow{6}{*}{$\begin{aligned} & 3.75 \\
\pm & .48651\end{aligned}$} \\
\hline & Creative thinking & $3.71 \pm 0.967$ & \\
\hline & Self-Managed Learning & $3.66 \pm 0.701$ & \\
\hline & Adaptively & $3.62 \pm 0.858$ & \\
\hline & Problem Solving & $3.44 \pm 0.951$ & \\
\hline & Computer Skills & $4.21 \pm 0.783$ & \\
\hline \multirow{7}{*}{ Participation } & Communication Skills & $3.35 \pm 0.932$ & \multirow{7}{*}{$\begin{array}{c}3.35 \\
\pm .5338\end{array}$} \\
\hline & $\begin{array}{c}\text { Interpersonal Skills and } \\
\text { group work }\end{array}$ & $3.32 \pm 0.848$ & \\
\hline & Active Learning & $3.34 \pm 0.878$ & \\
\hline & Feed back to assist learning & $3.03 \pm 1.113$ & \\
\hline & $\begin{array}{c}\text { Relationship between } \\
\text { teacher and } \\
\text { Student } \\
\end{array}$ & $3.42 \pm 0.851$ & \\
\hline & $\begin{array}{l}\text { Relationship with other } \\
\text { students }\end{array}$ & $3.63 \pm 1.93$ & \\
\hline & Cooperative learning & $3.22 \pm 0.88$ & \\
\hline \multirow{4}{*}{$\begin{array}{c}\text { Focused } \\
\text { Attention }\end{array}$} & Teaching for understanding & $3.37 \pm 0.810$ & \multirow{4}{*}{$\begin{aligned} & 3.25 \\
\pm & .48716\end{aligned}$} \\
\hline & Assessment & $3.38 \pm 0.701$ & \\
\hline & Workload & $2.49 \pm 1.059$ & \\
\hline & Coherence of curriculum & $3.68 \pm 0.796$ & \\
\hline
\end{tabular}

Comparing the all three domain of student engagement domain mean score, meaningful process showed a higher mean (3.75 \pm ) among other domain of student engagement as focused attention showed (3.25 \pm ) and participation had (3.35 \pm ) mean score. Computer skills (4.21 \pm ) and critical thinking were higher mean score among all the component of meaningful process. Relationship with other student/sense of belonging (3.63 \pm ) and relationship with teachers (3.42 \pm ) had a higher mean score among participation component of student engagement. Assessment (3.38 $)$ ) had higher mean score among focused attention component of student engagement. However,

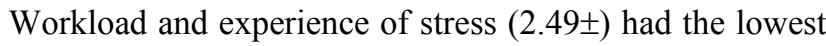
mean score among all component of student engagement.

\subsection{Interrelationship between the Benchmarks of Nursing Student Engagement}

Pearson correlation was performed to examine the relationship between the bench markers of student engagement scale. As in Table 3 shows that there is positive correlation among all three sub-domain of student engagement, moderate uphill relation is present between meaningful process and focused attention $(r=.461, p<$ $0.01)$ and meaningful process and participation $(\mathrm{r}=.486$, $\mathrm{p}<0.01)$. Which shows if one sub-domain increase it positively effect on the other sub-domain. 
Table 3. Pearson Correlation between benchmarks of Student engagement scales

\begin{tabular}{|c|c|c|c|c|}
\hline \multicolumn{5}{|c|}{ Correlations } \\
\hline & & \multicolumn{2}{|c|}{$\begin{array}{c}\text { Meaningful } \\
\text { Process }\end{array}$} & $\begin{array}{r}\text { Focused } \\
\text { Attention } \\
\end{array}$ \\
\hline \multirow{3}{*}{$\begin{array}{l}\text { Meaningful } \\
\text { Process }\end{array}$} & $\begin{array}{l}\text { Pearson } \\
\text { Correlation }\end{array}$ & 1 & $.263^{* *}$ & $.461^{* *}$ \\
\hline & Sig. (2-tailed) & & .002 & .000 \\
\hline & $\mathrm{N}$ & 131 & 131 & 131 \\
\hline \multirow{3}{*}{ Participation } & $\begin{array}{l}\text { Pearson } \\
\text { Correlation }\end{array}$ & $.263^{* *}$ & 1 & $.486^{* *}$ \\
\hline & Sig. (2-tailed) & .002 & & .000 \\
\hline & $\mathrm{N}$ & 131 & 135 & 135 \\
\hline \multirow{3}{*}{$\begin{array}{l}\text { Focused } \\
\text { Attention }\end{array}$} & $\begin{array}{l}\text { Pearson } \\
\text { Correlation } \\
\end{array}$ & $.461^{* *}$ & $.486^{* *}$ & 1 \\
\hline & Sig. (2-tailed) & .000 & .000 & \\
\hline & $\mathrm{N}$ & 131 & 135 & 135 \\
\hline
\end{tabular}

\subsection{Association between Nursing Student Engagement Benchmarking and Academic Outcome}

The Regression analysis performed to examine the association between student engagement and academic outcome. As Table 4 suggests p-value changes in the predictor are not associated with changes in the response, meaningful process $(p<.079)$, participation $(p<.666)$ and focused attention $(p<.313)$. Which shows that $(p<0.05)$ had higher value in all three bench markers which shows there is no association present between self-reported cGPA and student engagement of nursing student, and self-reported cGPA is not statically dependent on student engagement benchmarks.

Table 4. Regression analysis regarding nursing student engagement benchmarks and academic outcome

\begin{tabular}{|c|c|c|c|c|c|c|}
\hline \multicolumn{7}{|c|}{ Coefficients $^{a}$} \\
\hline \multirow{2}{*}{\multicolumn{2}{|c|}{ Model }} & \multicolumn{2}{|c|}{$\begin{array}{l}\text { Unstandardized } \\
\text { Coefficients }\end{array}$} & \multirow{2}{*}{$\begin{array}{c}\text { Standardized } \\
\text { Coefficients } \\
\text { Beta }\end{array}$} & \multirow[t]{2}{*}{$\mathrm{t}$} & \multirow[t]{2}{*}{ Sig. } \\
\hline & & B & Std. Error & & & \\
\hline \multirow{4}{*}{1} & (Constant) & 2.626 & .397 & & 6.619 & .000 \\
\hline & $\begin{array}{l}\text { Meaningful } \\
\text { Process }\end{array}$ & .179 & .101 & .175 & 1.770 & .079 \\
\hline & Participation & .040 & .093 & .044 & .432 & .666 \\
\hline & $\begin{array}{l}\text { Focused } \\
\text { Attention }\end{array}$ & -.113 & .111 & -.111 & -1.013 & .313 \\
\hline
\end{tabular}

\section{Chapter Five}

\subsection{Discussion}

As result shows that majority of participants were between the age group of 23-27 years old, female were in large number than males. Mostly students held cGPA "B" and some held " $A$ " and " $C$ ". Most of the participants belong to cohort 2015, and large number students enrolled in BSN Post RN 2years.
Participants scored higher mean in all domain of student engagement. Student were engage in all domain of engagement positively. In meaningful process mostly participants scored a higher mean compared to participation and focused attention. In meaningful process highest mean scores were of critical thinking, creative thinking and computer literacy. Similarly result obtained in a study conduct in Muscat, Oman among Nursing students which shows that student had a higher mean score in critical thinking, problem solving, creative thinking and computer literacy [22]. As Sagayadevan and Jeyaraj [24] described in his study that emotional engagement is essential for academic outcome as such learning environment, and it is the domain of engagement which not only help to engage student in learning environment but also it is the analyst of observing staff interaction on student engagement and help teacher to modify their teaching styles according to the need of students.

However, there is lowest mean scored in the focused attention component of workload and experience of stress. Similar result obtained in one of study which was also conducting on nursing student in Longview University Center, University of Texas, studies shows the similar result of lowest mean in experience of stress [21]. In another study which is conducted in China shows that student exhibit high level of stress perception through their studies workload. Study suggest that if there is heavy workload on student it will affect negatively on student and their learning. However, it is not important that for coping this problem start to limit the assignment instead scheduled the assignment and other work in that manner that student don't experience all the burden at the end of semester. So, it don't effect on learning of student [25].

In this study statically analysis shows that there is no association between bench markers of student engagement and student self-reported learning outcome. Another research in this regard conducted in Boston University on master's students, it also shows the similar result that there is no relation between self-reported grade point average and engagement of student $[26,27]$. Through these studies it exhibit that there is not necessarily association present between engagement and outcome it is not the final predictor to assess student learning outcome. Both studies favored that student who hold low GPA try to engage more in their learning environment to get better results in future.

\subsection{Limitation}

There were several limitation in this study. First, sample size was small, cross-sectional study sample size should be large to get accurate result from study participants. Second, self-report questions was another limitation in this study, it is mostly effect the study with biasness. Thirdly, student engagement is basic concern of every organization. To truly explore or estimate the engagement of students quantitative study is not just enough because student engagement in learning environment have many areas of focus, to explore it needs to study each area solely by qualitative method. 


\subsection{Conclusion}

This study explored nursing student engagement in their learning environment, result shows that student are positively engaged in domain of meaningful process, which have the basic focus in nursing education because it allow a student to also react positively in their clinical environment when they are attending patients. Participation domain have also important in class room and clinical setting to become a productive learner and professional, result shows that student had positive attitude in the behavioral engagement area. However, result shows that nursing student experience workload and stress in their learning environment, which should be deal to increase their productivity not only in class room but also in clinical setting. At the end study didn't shows a relation between engagement and student self-reported GPA.

\subsection{Recommendations}

There should be a stress management programs on weekly bases and need to further investigate this area. Because if student are unable to manage their workload stress it will not effect on their class work but also effect whole area of engagement. As study suggest that student perception of stress could not be dealt by limiting their number of assignment but it can be managed by starting their assignment at very start of semester so it will create a flow to end. Student will not feel the burden at end due to gathered pile of projects [25].

\section{References}

[1] Hudson, K. F. (2015). Nursing Student Engagement: Student, Classroom, and Clinical Engagement. International Journal of Nursing, 4(1).

[2] Thomas, L. (2012). Building student engagement and belonging in Higher Education at a time of change. Paul Hamlyn Foundation, 100.

[3] McClenney, K., Marti, C. N., \& Adkins, C. (2012). Student Engagement and Student Outcomes: Key Findings from. Community College Survey of Student Engagement.

[4] Kember, D., Leung, D. Y., \& Ma, R. S. (2007). Characterizing learning environments capable of nurturing generic capabilities in higher education. Research in Higher Education, 48(5), 609.

[5] Baum, S., Ma, J., \& Payea, K. (2010). Education Pays, 2010: The Benefits of Higher Education for Individuals and Society. Trends in Higher Education Series. College Board Advocacy \& Policy Center.

[6] Carnevale, A. P., \& Rose, S. J. (2011). The Undereducated American. Georgetown University Center on Education and the Workforce.

[7] Greenwood, C. R., Horton, B. T., \& Utley, C. A. (2002). Academic engagement: Current perspectives on research and practice. School Psychology Review, 31(3), 328.
[8] Crosling, G., Heagney, M., \& Thomas, L. (2009). Improving student retention in higher education: Improving teaching and learning. Australian Universities' Review, 51(2), 9-18.

[9] Kuh, G. D., Kinzie, J., Buckley, J. A., Bridges, B. K., \& Hayek, J. C. (2011). Piecing together the student success puzzle: research, propositions, and recommendations: ASHE Higher Education Report (Vol. 116): John Wiley \& Sons.

[10] Astin, A. W. (1984). Student involvement: A developmental theory for higher education. Journal of college student personnel, 25(4), 297-308.

[11] Fry, H., Ketteridge, S., \& Marshall, S. (2008). A handbook for teaching and learning in higher education: Enhancing academic practice: Routledge.

[12] Felder, R. M., \& Brent, R. (2007). Cooperative learning: ACS Publications.

[13] Iyer, R. B. (2013). Relation between cooperative learning and student achievement. International Journal of Education and Information Studies, 3(1), 21-25.

[14] Hagenauer, G., \& Volet, S. E. (2014). Teacher-student relationship at university: an important yet under-researched field. Oxford Review of Education, 40(3), 370-388.

[15] Lai, E. R. (2011). Critical thinking: A literature review. Pearson's Research Reports, 6, 40-41.

[16] Carini, R. M., Kuh, G. D., \& Klein, S. P. (2006). Student engagement and student learning: Testing the linkages. Research in Higher Education, 47(1), 1-32.

[17] Steckler, R. (2012). Improving communication skills among nursing students: Assessing the comfort curriculum as an intervention.

[18] Hazelwood, Z. J. (2015). Maintaining student engagement in a multidisciplinary allied health communication skills course. Paper presented at the Students Transitions Achievement Retention \& Success (STARS) Conference 2015 Handbook \& Proceedings.

[19] Ko, J. W., Park, S., Yu, H. S., Kim, S.-J., \& Kim, D. M. (2016). The structural relationship between student engagement and learning outcomes in Korea. The Asia-Pacific Education Researcher, 25(1), 147-157.

[20] guNuc, S. (2014). The relationship between Student engagement and their academic achievement. International Journal on New Trends in Education and Their Implications, 5(4), 216-231.

[21] Hudson, K., \& Carrasco, R. (2017). Nursing Student Engagement: Taking a Closer Look. Open Journal of Nursing, 7(02), 193.

[22] D'Souza, M. S., Isac, C., Venkatesaperumal, R., Nairy, K. S., \& Amirtharaj, A. (2013). Exploring nursing student engagement in the learning environment for improved learning outcomes. Clinical Nursing Studies, 2(1), p1.

[23] Kember, D., \& Leung, D. Y. (2005). The influence of the teaching and learning environment on the development of generic capabilities needed for a knowledge-based society. Learning environments research, 8(3), 245-266.

[24] Sagayadevan, V., \& Jeyaraj, S. (2012). The role of emotional engagement in lecturer-student interaction and the impact on academic outcomes of student achievement and learning. Journal of the Scholarship of Teaching and Learning, 12(3), 1-30.

[25] Lam, P., McNaught, C., Lee, J., \& Chan, M. (2012). The impact of student workload on learning experiences: Working Paper.

[26] O'Dair, K. G. (2012). Measuring master's student engagement: Boston College.

[27] Popkess, A. M. (2010). The relationship between undergraduate, baccalaureate nursing student engagement and use of active learning strategies in the classroom. Indiana University. 